\title{
Article
}

\section{The Effect of Chronic Iloperidone Treatment on Cytochrome P450 Expression and Activity in the Rat Liver: Involvement of Neuroendocrine Mechanisms}

\author{
Przemysław J. Danek (1), Wojciech Kuban $(\mathbb{D}$ and Władysława A. Daniel *(1) \\ Department of Pharmacokinetics and Drug Metabolism, Maj Institute of Pharmacology, Polish Academy of \\ Sciences, Smętna 12, 31-343 Kraków, Poland; danek@if-pan.krakow.pl (P.J.D.); kuban@if-pan.krakow.pl (W.K.) \\ * Correspondence: nfdaniel@cyf-kr.edu.pl; Tel.: +48-12-6623266; Fax: +48-12-6374500
}

Citation: Danek, P.J.; Kuban, W.; Daniel, W.A. The Effect of Chronic Iloperidone Treatment on

Cytochrome P450 Expression and Activity in the Rat Liver: Involvement of Neuroendocrine Mechanisms. Int. J. Mol. Sci. 2021, 22, 8447. https:// doi.org/10.3390/ijms22168447

Academic Editor: Fabio Altieri

Received: 15 July 2021

Accepted: 3 August 2021

Published: 6 August 2021

Publisher's Note: MDPI stays neutral with regard to jurisdictional claims in published maps and institutional affiliations.

Copyright: () 2021 by the authors. Licensee MDPI, Basel, Switzerland. This article is an open access article distributed under the terms and conditions of the Creative Commons Attribution (CC BY) license (https:// creativecommons.org/licenses/by/ $4.0 /)$.

\begin{abstract}
In order to achieve a desired therapeutic effect in schizophrenia patients and to maintain their mental wellbeing, pharmacological therapy needs to be continued for a long time, usually from the onset of symptoms and for the rest of the patients' lives. The aim of our present research is to find out the in vivo effect of chronic treatment with atypical neuroleptic iloperidone on the expression and activity of cytochrome P450 (CYP) in rat liver. Male Wistar rats received a once-daily intraperitoneal injection of iloperidone $(1 \mathrm{mg} / \mathrm{kg})$ for a period of two weeks. Twenty-four hours after the last dose, livers were excised to study cytochrome P450 expression (mRNA and protein) and activity, pituitaries were isolated to determine growth hormone-releasing hormone (GHRH), and blood was collected for measuring serum concentrations of hormones and interleukin. The results showed a broad spectrum of changes in the expression and activity of liver CYP enzymes, which are important for drug metabolism (CYP1A, CYP2B, CYP2C, and CYP3A) and xenobiotic toxicity (CYP2E1). Iloperidone decreased the expression and activity of CYP1A2, CP2B1/2, CYP2C11, and CYP3A1/2 enzymes but increased that of CYP2E1. The CYP2C6 enzyme remained unchanged. At the same time, the level of GHRH, GH, and corticosterone decreased while that of $\mathrm{T}_{3}$ increased, with no changes in IL-2 and IL-6. The presented results indicate neuroendocrine regulation of the investigated CYP enzymes during chronic iloperidone treatment and suggest a possibility of pharmacokinetic/metabolic interactions produced by the neuroleptic during prolonged combined treatment with drugs that are substrates of iloperidone-affected CYP enzymes.
\end{abstract}

Keywords: iloperidone; prolonged administration; rat liver; cytochrome P450 expression/activity; hormone levels; neuroendocrine regulation

\section{Introduction}

Cytochrome P450 enzymes (CYPs) are a large class of heme-containing monooxygenases that catalyze NADPH-dependent $\mathrm{C}-, \mathrm{N}-$, and S-oxidation and $\mathrm{O}-, \mathrm{N}-$, and S-dealkylation of substrates. CYP enzymes are responsible for the metabolism of endogenous substrates, such as hormones, vitamins, arachidonic acid, bile acid, or steroids including neurosteroids, and for catalyzing the oxidation of exogenous substrates, such as xenobiotics and drugs of different pharmacological groups, including psychotropics [1,2].

Iloperidone is an atypical neuroleptic drug approved for the treatment of acute schizophrenia in adult patients [3]. Iloperidone, like other atypical neuroleptics, displays high and strong antagonistic activity and higher affinity for serotonin $5-\mathrm{HT}_{2 \mathrm{~A}}$ than dopamine $\mathrm{D}_{2}$ receptors [4]. It also has a high affinity for $\alpha_{1}$ and $\alpha_{2}$ adrenoreceptors and for dopamine $\mathrm{D}_{3}$ receptors; moderate affinity for dopamine $\mathrm{D}_{4}$, and serotonin $5-\mathrm{HT}_{6}$ and $5-\mathrm{HT}_{7}$; low affinity for serotonin $5-\mathrm{HT}_{1 \mathrm{~A}}$, dopamine $\mathrm{D}_{1}$, and histamine $\mathrm{H}_{1}$ receptors; and no affinity for cholinergic muscarinic receptors [5-7]. The drug is metabolized mainly by CYP2D6 (via carbonyl reduction and hydroxylation) and to a lesser degree by CYP3A4 (via O-demethylation) [3]. Compared with other typical neuroleptics, iloperidone is associated 
with a low incidence of akathisia and extrapyramidal symptoms [8] and a low propensity to elevate prolactin levels or to change metabolic parameters [9].

The physiological and pharmacological regulation of cytochrome P450 activity in the liver may proceed via different direct and indirect pathways. The direct mechanisms include drug binding to the enzyme, which can lead to the inhibition of enzyme activity via a competitive, noncompetitive, or mixed mechanism [10,11]. On the other hand, the indirect regulation of enzyme activity may involve both peripheral (e.g., drug binding to the hepatic membrane, and cytosolic or nuclear receptors) and central mechanisms. The central mechanisms engage the brain's nervous and endocrine systems, thus leading to the neuroendocrine regulation of CYP gene expression. This kind of mechanism has been shown to involve the brain's dopaminergic, noradrenergic, and serotonergic systems in combination with the hypothalamic endocrine center [12-15].

Considering the abovementioned possibilities of drug influence on cytochrome P450, in vitro models may be used to examine the direct and indirect peripheral mechanisms taking place in the liver (e.g., liver slices, hepatocyte cultures, liver microsomes, or cDNAexpressed CYPs). However, studying the drug effects on CYP regulation in the liver mediated by central mechanisms requires in vivo models, whereby the brain's nervous system (via its receptors located on hypothalamic endocrine cells) can act on peripheral endocrine glands and, in turn, on liver function [15-17].

To produce and maintain the therapeutic effect in schizophrenia, neuroleptic drugs have to be administered to patients for a long period of time (months or years). It creates the possibility for different kinds of interactions (direct and indirect) of the applied drugs with receptors, enzymes, or genes encoding those biologically active proteins. Thus, drugs acting on the central nervous system should be investigated both in vitro and in vivo to discover all possibilities of their interaction with cytochrome P450. Our previous studies showed that iloperidone directly inhibited CYP2C19, CYP2D6, and CYP3A4 in liver microsomes via mixed, competitive, or noncompetitive mechanisms, respectively [18], and diminished the CYP3A4 expression in hepatocyte cultures [19]. The aim of our present research was to find out the in vivo effect of a two-week treatment with iloperidone on the expression and activity of liver cytochrome P450 enzymes, which are known to undergo neuroendocrine regulation.

\section{Results}

\subsection{The Effect of Chronic Treatment with Iloperidone on the CYP Activity in Rat Liver Microsomes}

The administration of iloperidone to rats for two weeks decreased the activity of CYP1A, i.e., C-8-hydroxylation and 3-N-demethylation, down to $68 \%$ and $71 \%$ of the control, respectively. Iloperidone diminished the activity of CYP2B (testosterone 16ßhydroxylation) down to $67 \%$ of the control; that of CYP2C11 (testosterone $2 \alpha$ - and $16 \alpha-$ hydroxylation) to $69 \%$ and $67 \%$ of the control, respectively; and that of CYP3A (testosterone $2 \beta$ - and $6 \beta$-hydroxylation) to $83 \%$ and $71 \%$ of the control, respectively. In contrast, prolonged treatment of animals with iloperidone increased the activity of CYP2E1 (chlorzoxazone 6-hydroxylation) up to $115 \%$ of the control.

The activities of CYP2C6 (warfarin 7-hydroxylation) and CYP2A (testosterone $7 \alpha$ hydroxylation) were not significantly affected by iloperidone (Figure 1). 


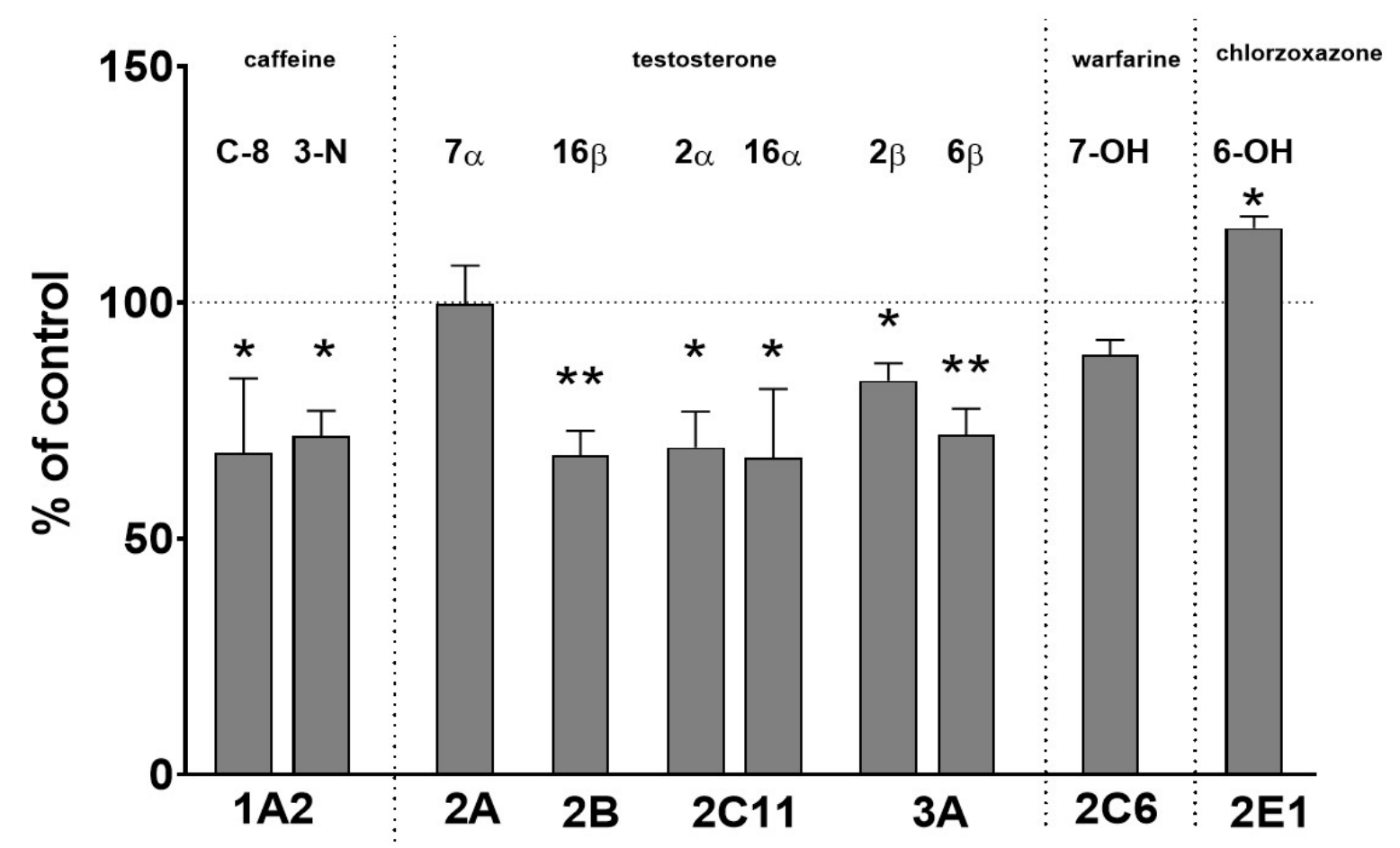

Figure 1. The effect of two-week treatment with iloperidone on cytochrome P450 enzyme activities, measured as the rates of CYP-specific reactions in rat liver microsomes: caffeine 8-hydroxylation and 3-N-demethylation (CYP1A); testosterone $7 \alpha-(\mathrm{CYP} 2 \mathrm{~A}), 16 \beta-(\mathrm{CYP} 2 \mathrm{~B}), 2 \alpha-$, and 16 $\alpha$ - (CYP2C11); $2 \beta-$ and $6 \beta-(\mathrm{CYP3A})$ hydroxylation; warfarin 7-hydroxylation (CYP2C6); and chlorzoxazone 6-hydroxylation (CYP2E1). All values are shown as the mean \pm S.E.M. $(n=12)$. Statistical significance was assessed by Student's t-test and marked as ${ }^{*} p<0.05 ;{ }^{* *} p<0.01$, compared with the control. The control values (picomoles per milligram protein per minute) are as follows: $11.28 \pm 3.07$ (8-hydroxy-caffeine); $1.74 \pm 0.6$ (3-Ndemethyl-caffeine); $134 \pm 35,130 \pm 36.5,767.8 \pm 281.1,910 \pm 372.7,33.9 \pm 7.5$, and $658.4 \pm 164.6\left(7 \alpha_{-}, 16 \beta-, 2 \alpha_{-}, 16 \alpha_{-}\right.$, $2 \beta$-, and $6 \beta$-hydroxy-testosterone, respectively); $4.86 \pm 1.28$ (7-hydroxy-warfarin); and $3.22 \pm 0.34$ (nmol/mg protein/min, 6-hydroxy-chlorzoxazone).

\subsection{The Influence of Two-Week Treatment with Iloperidone on the CYP Protein Level in Rat Liver Microsomes}

CYP enzymes that are important for drug metabolism, and for which significant activity changes were detected, were then chosen for expression measurements at the mRNA and protein levels. The observed changes in CYP protein levels corresponded well with the alteration in CYP activities. The CYP1A protein level fell down to about $75 \%$ of the control. The levels of CYP2B1 and CYP2B2 proteins were reduced by the neuroleptic to $72 \%$ and $79 \%$ of the control, respectively. Iloperidone significantly decreased the CYP2C11 protein to $78 \%$ of the control. The CYP3A1 and CYP3A2 protein levels were lowered by iloperidone to $58 \%$ and $75 \%$ of the control. On the other hand, the neuroleptic increased the CYP2E1 protein level up to $145 \%$ of the control (Figure 2).

\subsection{The Effect of Iloperidone Treatment on the mRNA Level of CYP Enzymes in the Liver}

In parallel with the changes in activity and protein levels, the investigated neuroleptic produced a significant decrease in the mRNA level of the CYP1A2 gene down to 77\% of the control. Iloperidone reduced the CYP2B1 and CYP2B2 mRNA levels to 77\% and $74 \%$ of the control. The level of CYP2C11 mRNA was diminished to $77 \%$ of the control after iloperidone treatment. The CYP3A1 and CYP3A2 mRNA levels were reduced by the investigated drug to $68 \%$ and $82 \%$ of the control, respectively. The examined drug did not produce any significant changes in the CYP1A1 mRNA levels. On the other hand, the neuroleptic increased the CYP2E1 mRNA level to 138\% of the control (Figure 3). 

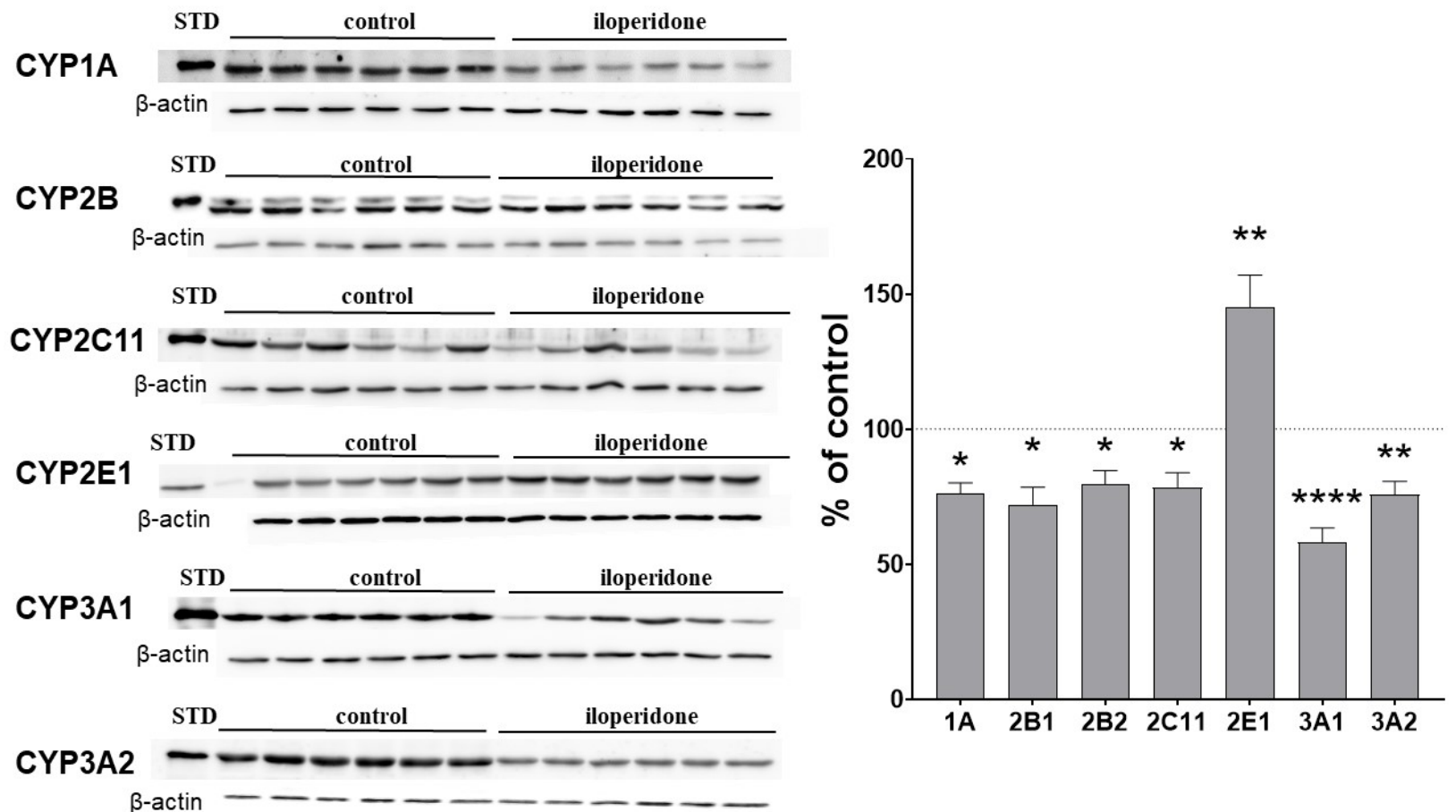

Figure 2. The effect of two-week treatment with iloperidone on the protein levels of CYP1A, CYP2B, CYP2C11, CYP3A, and CYP2E1 enzymes in rat liver microsomes. Microsomal proteins $(10 \mu \mathrm{g})$ were subjected to the Western immunoblot analysis. The results are presented as representative blots from six (for the control and for iloperidone treatment) separate rats per treatment. The data are expressed as the mean \pm S.E.M. $(n=12)$. Statistical significance was assessed by Student's $t$-test and marked as $*<0.05,{ }^{* *} p<0.01, * * * * 0.0001$, compared with the control.

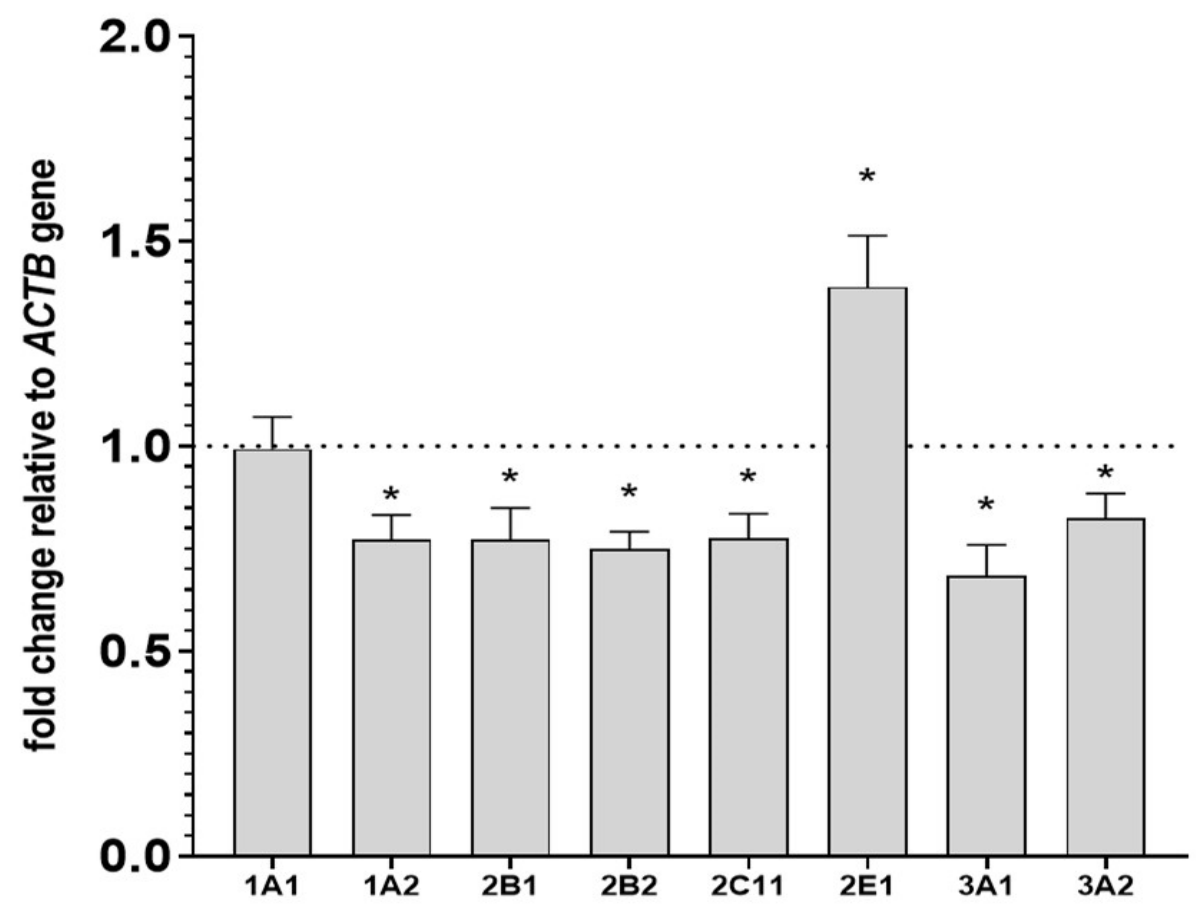

Figure 3. The effect of two-week treatment with iloperidone on the mRNA levels of CYP1A, CYP2B, CYP2C11, CYP3A, and CYP2E1 genes in the liver. The results are expressed as the fold-change in relation to the ACTB housekeeping gene. All the values are the mean fold-change calculated by the comparative delta-delta $\mathrm{Ct}$ method for the control and iloperidone-treated rats. All values are the means \pm S.E.M. $(n=10)$. The significance of differences between the results was calculated using Student's $t$-test. Statistical significance is shown as $* p<0.05$ vs. control group. 


\subsection{The Effect of Two-Week Treatment with Iloperidone on the Pituitary GHRH and Serum Concentrations of Hormones and Cytokines}

The level of growth hormone-releasing hormone (GHRH) in the pituitary gland decreased to $76 \%$ of the control after chronic treatment with iloperidone. The ELISA test revealed a significant decrease in the serum concentration of corticosterone and growth hormone (to $84 \%$ and $90 \%$ of the control, respectively) and an increase in the thyroid hormone triiodothyronine $\left(\mathrm{T}_{3}\right)$ (to $111 \%$ of the control). The concentration of thyroxine $\left(\mathrm{T}_{4}\right)$ was not significantly changed by iloperidone treatment (Figure 4). No changes in the serum concentration of the investigated interleukins (IL-2 and IL-6) were observed after chronic iloperidone treatment (Figure 4).

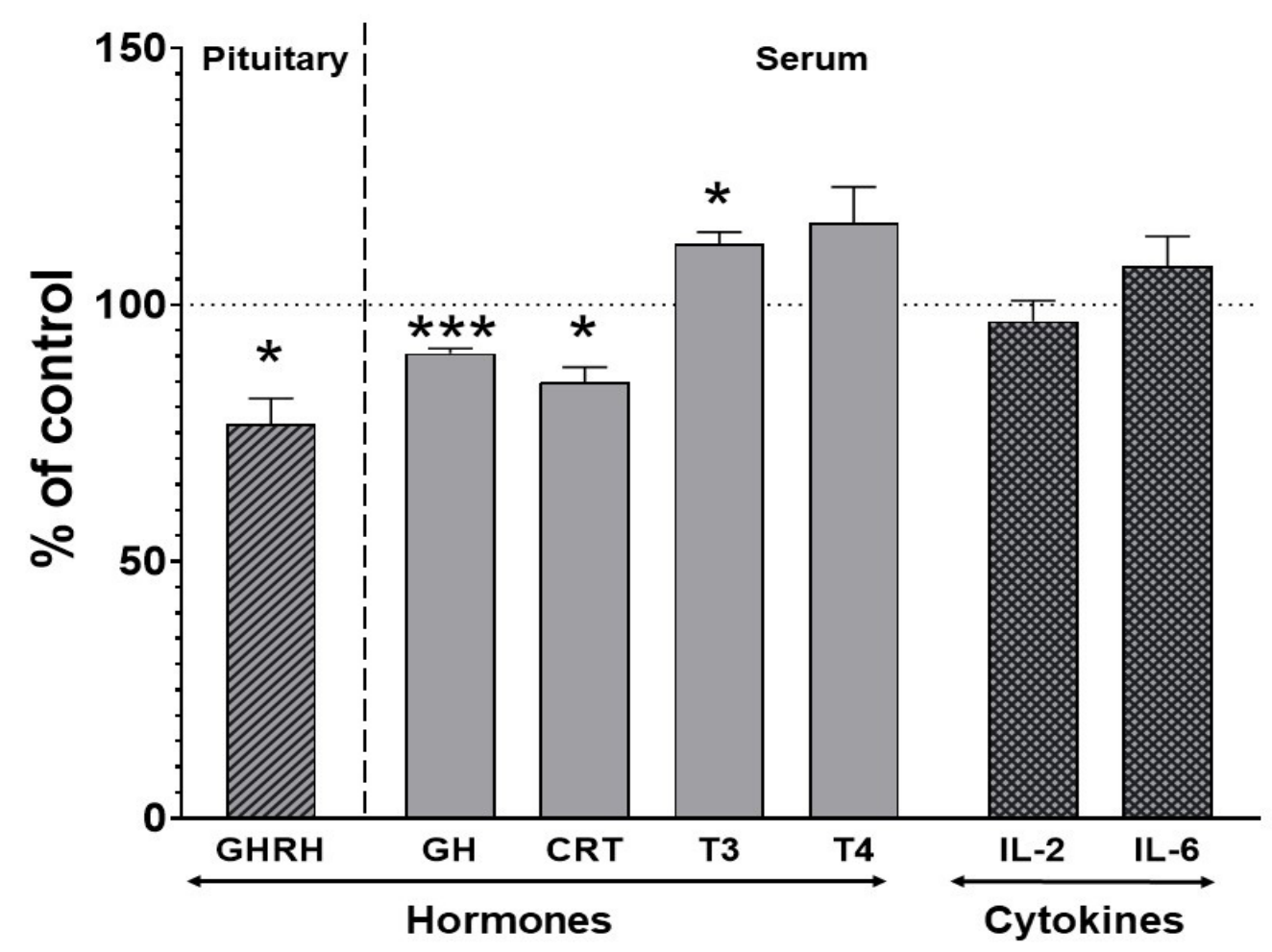

Figure 4. The effect of two-week treatment with iloperidone on the levels of pituitary and serum hormones and serum cytokine concentrations. All the values are the mean \pm S.E.M. of the control $(n=12)$ and iloperidone-treated $(n=12)$ group. Statistical significance was assessed by Student's $t$-test and is shown as ${ }^{*} p<0.05$ or ${ }^{* * *} p<0.001$ compared with the control. The absolute control values were $34.14 \pm 4.02 \mathrm{ng} / \mathrm{mg}$ for pituitary growth hormone-releasing hormone (GHRH) and $6.3 \pm 0.16 \mathrm{ng} / \mathrm{mL}, 18.19 \pm 2.91 \mathrm{ng} / \mathrm{mL}, 1.12 \pm 0.054 \mathrm{ng} / \mathrm{mL}, 3.03 \pm 1.18 \mathrm{ng} / \mathrm{mL}, 66.06 \pm 8.39 \mathrm{ng} / \mathrm{mL}, \mathrm{and} 1.1 \pm 0.15 \mathrm{ng} / \mathrm{mL}$ for serum growth hormone $(\mathrm{GH})$, corticosterone $(\mathrm{CRT})$, triiodothyronine $\left(\mathrm{T}_{3}\right)$, thyroxine $\left(\mathrm{T}_{4}\right)$, interleukin-2 (IL-2), and interleukin-6 (IL-6), respectively.

\section{Discussion}

To achieve a desired therapeutic effect in schizophrenia patients and to maintain their mental wellbeing, pharmacological therapy needs to be continued for a long time, usually from the onset of symptoms and for the rest of the patient's lives. Such a long therapy, which is often prescribed in combination with different drugs, may influence the expression of biologically active proteins including drug metabolizing enzymes and may lead to metabolic interactions. This work is the first report showing changes in the expression and activity of cytochrome P450, the main enzyme responsible for oxidative drug metabolism, which are produced by chronic treatment with pharmacological doses of the novel atypical neuroleptic iloperidone.

The results show a broad spectrum of changes in liver CYP enzymes, which are important for the metabolism of drugs (CYP1A, CYP2B, CYP2C, and CYP3A) and small 
toxic xenobiotics (CYP2E1). It is worth noting that the observed decreases in the CYP enzyme activities correlate well with simultaneous lowering in the enzyme protein and mRNA levels, which points to the inhibition of the transcription of genes coding for those CYP proteins (i.e., CYP1A2, CYP2B1, CYP2B2, CYP2C11, CYP3A1, and CYP3A2). Interestingly, the decreases in the expression and activity of the abovementioned CYP genes were accompanied with parallel changes in CYP-regulating hormone levels.

The diminished levels of pituitary growth hormone-releasing hormone (GHRH) and serum growth hormone $(\mathrm{GH})$ correlated positively with the decreased expression of $C Y P 2 C 11$ and $C Y P 3 A 1 / 2$ in the rat livers. GH produced by the pituitary and acting via its hepatic membrane receptor (GHR) is the main positive regulator of CYP2C11 expression and plays an important role in the upregulation of $C Y P 3 A$ genes $[20,21]$. The diminished concentration in serum corticosterone, a positive regulator of the CYP1A, CYP2B, and CYP3A genes acting via its nuclear receptor (GR) [22-26], also positively correlated with the observed reduction in the expression of those genes in the iloperidone-treated rats. On the other hand, an increase in the serum concentration of thyroid hormone $\mathrm{T}_{3}$, which is known to negatively influence the cytochrome $\mathrm{P} 450$ expression via its nuclear receptor (THR) [27-29], negatively correlated with the decreased expression of the CYP1A, CYP2B, CYP2C, and CYP3A enzymes found after prolonged administration of iloperidone. Our results are in line with the known molecular mechanisms of cytochrome P450 regulation by the cytosolic aryl hydrocarbon receptor (AHR) or the nuclear receptors: pregnane $X$ receptor (PXR), constitutive androstane receptor (CAR), and retinoic $X$ receptor (RXR). GR receptors contribute to the regulation of CYP3A, CYP2B, and CYP2C genes through a direct or an indirect molecular mechanism, including a functional cross-talk among GR, PXR, CAR, and RXR. The expressions of PXR, CAR, and RXR are activated by glucocorticoids and xenobiotics [25,30-32]. AhR, which is primarily responsible for the regulation of CYP1A enzymes, is also modulated by physiological levels of glucocorticoids and sex hormones [23]. Natural steroids, such as androgens or pregnanes, which are ligands for the nuclear receptors PXR and/or CAR, can directly affect CYP2B, CYP2C, or CYP3A expression in the liver [33]. Therefore, it seems that iloperidone indirectly affects cytochrome P450 via a decrease in corticosterone concentration and, in turn, decreased activation of GR, though a direct action on one of the abovementioned nuclear receptors cannot be excluded. It is worth noting that the serum concentrations of interleukins, which downregulate CYP enzymes (IL-2 and IL-6), were not changed by iloperidone. The activity of CYP2C6 enzyme, which is less vulnerable to hormonal changes, was not affected by iloperidone treatment.

In contrast with the above-discussed decreases in the expression and activity of the CYP1A, CYP2B, CYP2C11, and CYP3A enzymes, the expression and activity of the CYP2E1 enzyme was increased by chronic iloperidone treatment. The CYP2E1 enzyme is less engaged in drug metabolism compared with other members of CYP2 family and is involved only in the biotransformation of a few drugs (chlorzoxazone, acetaminophen, isoniazid, lidocaine, coumarin derivatives, and gaseous anesthetics). However, it is important for the metabolism of small-molecular hydrophobic compounds, such as acetone or alcohol, and catalyzes the oxidation of procarcinogens (vinyl chloride or bromide, dimethyl- or diethyl-nitrosamine, acrylonitrile, urethane, styrene, benzene, CCL4, chloroform, and trichloroethylene) [34]. Therefore, the induction of CYP2E1 is not desirable for maintaining the correct (safe) rate of biochemical processes in the organism [35,36]. Alcohol, acetone, and long starvation induce the enzyme, and iloperidone seems to have a similar property, though its effect on the enzyme activity is less potent. CYP2E1 is known to be induced at different levels, i.e., at the transcriptional, posttranscriptional, and posttranslational levels [37-41]. In the case of the investigated neuroleptic, regulation at the transcriptional level occurs, as the drug increases the CYP2E1 mRNA, CYP2E1 protein, and enzyme activity with good positive correlation. The observed increase in CYP2E1 expression and activity may be connected (at least partially) with iloperidone-evoked inhibition of the GHRH-GH hormonal axis and increased $\mathrm{T}_{3}$ serum concentration. It has been demonstrated in different animal models that CYP2E1 is negatively regulated by GH [42-48] but positively by $\mathrm{T}_{3}$ [49]. 
Since the CYP2E1 enzyme is well conserved among species, its regulation may be similar in rats and humans. Thus, further studies in this direction concerning human CYP2E1 in relation to different iloperidone doses are advisable to find out whether the drug is capable of enhancing the enzyme activity in the human liver.

Considering our previous results obtained using in vitro models and the present results obtained in vivo after chronic treatment with iloperidone, it can be concluded that the neuroleptic can affect liver cytochrome P450 via different direct and indirect mechanisms operating at the level of the liver and the whole organism, which involve (1) direct inhibition by binding to the enzyme via mixed, competitive, or noncompetitive mechanism, as shown for CYP2C19, CYP2D6, and CYP3A4, respectively, in liver microsomes [18]; (2) reduction in enzyme expression and activity at the level of hepatocyte, as shown for CYP3A4 in cell culture [19]; and (3) neuroendocrine regulation, as shown in the present in vivo study for many CYP enzymes after chronic treatment with iloperidone (Figure 5).

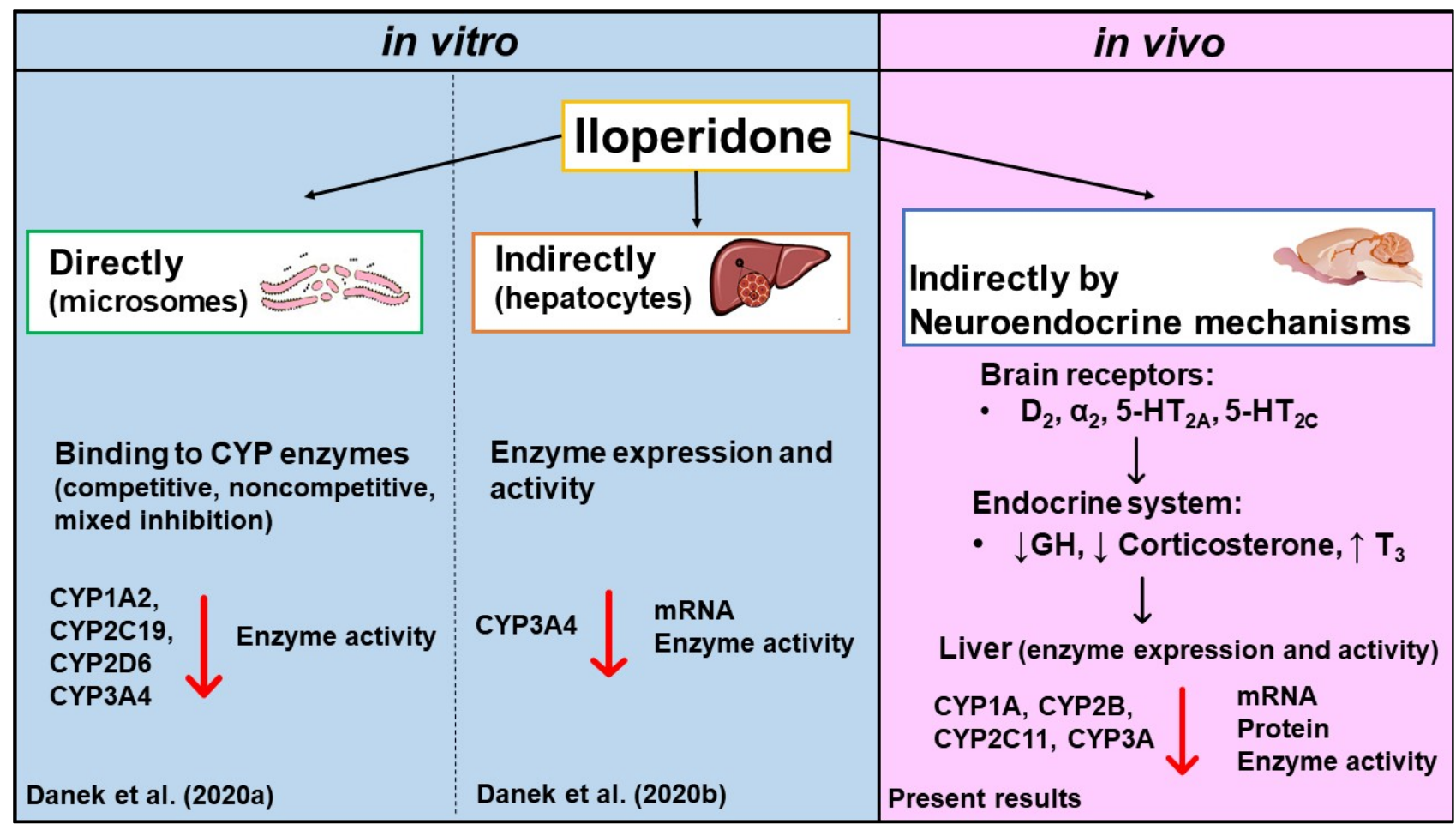

Figure 5. The effect of iloperidone on liver cytochrome P450 shown in different experimental models. The engagement of direct and indirect mechanisms in the interaction between the neuroleptic and CYP enzymes.

The observed inhibitory effect of iloperidone on the CYP1A, CYP2B, CYP2C, CYP2D, and CYP3A subfamilies may lead to pharmacokinetic (metabolic) interactions with coadministered drugs. Considering the similarities in regulation, amino acid sequence homology, and function between the tested rat CYPs and respective human CYPs, pharmacokinetic interactions with CYP-metabolized substrates (steroids, drugs, and carcinogens) can be expected in iloperidone-treated patients. Thus, the presented results may have serious medical implications. Changes in patient susceptibility to drugs should be taken into account by physicians who also need to monitor pharmacotherapy. For example, newer antidepressants and second-generation antipsychotic drugs are often used by clinicians, which may lead to pharmacokinetic and pharmacodynamic interactions [50]. On the other hand, stimulation of the CYP2E1-mediated metabolism of drugs, alcohol, and procarcinogens by iloperidone should also be considered and further investigated. 


\section{Materials and Methods}

\subsection{Chemicals and Reagents}

Iloperidone was obtained from TargetMol (Boston, MA, USA). Steraloids (Newport, KY, USA) provided testosterone and its metabolites. Caffeine and its metabolites, chlorzoxazone and its metabolite 6-hydroxychlorzoxazone, bufuralol and its metabolite 1'-hydroxybufuralol, glucose-6-phosphate-dehydrogenase, glucose-6-phosphate, NADP, NADPH, RNA-free water, and Tween 80 were purchased from Sigma (St. Louis, MO, USA). Warfarin was donated by Merck (Darmstadt, Germany). 7-Hydroxywarfarin was synthesized at the Maj Institute of Pharmacology, Kraków, Poland (Daniel et al. 2006). For RNA isolation, a Total RNA Mini kit purchased from A\&A Biotechnology (Gdynia, Poland) was used. A High-Capacity cDNA Reverse Transcription Kit, TaqMan assays, and the TaqMan Gene Expression Master Mix were supplied by Life Technologies (Carlsbad, CA, USA). The primary rabbit polyclonal anti-rat CYP1A1/2, CYP3A1, and CYP3A2 antibodies (Millipore, Temecula, USA); anti-rat CYP2C11 and CYP2E1 antibodies (Thermo Fisher Scientific, Walthman, MA, USA); monoclonal mouse anti-rat CYP2B1/2B2 (Santa Cruz Biotechnology, Dallas, TX, USA); and polyclonal anti-rat $\beta$-actin antibody (Sigma, St. Louis, MO, USA) were used. Horseradish peroxidase-labeled secondary antibodies, goat antimouse antibodies (Jackson ImmunoResearch, West Grove, PA, USA), and goat anti-rabbit antibodies (Vector Laboratories, Burlingame, CA, USA) were used. Rat cDNA-expressed CYP1A2, CYP2B1, CYP2C11, CYP2E1, CYP3A1, and CYP3A2 (Supersomes) were from Gentest Corp. (Woburn, MA, USA). The chemiluminescence reagents SuperSignal West Pico PLUS Chemiluminescent Substrate kit came from Thermo Fisher Scientific (Walthman, MA, USA). The ELISA kits for growth hormone, corticosterone, $\mathrm{T}_{3}, \mathrm{~T}_{4}, \mathrm{Il}-2$, and Il-6 were obtained from Bioassay Technology Laboratory (Bioassay Technology Laboratory, Shanghai, China). The kit for growth hormone-releasing hormone (GHRH) came from MyBiosource (San Diego, CA, USA). All necessary chemicals of the highest purity used for analysis by high-performance liquid chromatography (HPLC) were donated by Merck (Darmstadt, Germany).

\subsection{Animals}

Male Wistar Han rats (Charles River Laboratories, Sulzfeld, Germany), three months old and weighing 280-300 g, were initially acclimatized and housed (6 per cage) in environmentally controlled rooms (ambient temperature $22 \pm 2{ }^{\circ} \mathrm{C}$, humidity $50 \pm 5 \%$, and 12:12 light:dark cycle). The animals had free access to tap water and typical laboratory food. All animal procedures were conducted in strict accordance with the European regulations for animal experimentation on the Protection of Animals Used for Scientific Purposes (EU Directive 2010/63/EU). The experimental protocols were approved by the Local Ethics Commission for Experimentation on Animals at the Maj Institute of Pharmacology, Polish Academy of Sciences, Kraków.

\subsection{Drug Treatment and Liver Sample Preparation}

The rats ( $n=12$ for each treatment group) received intraperitoneal injections of iloperidone $(1 \mathrm{mg} / \mathrm{kg})$ or vehicle control (1\% Tween 80 in sterile water) once daily for a period of two weeks. The iloperidone solution for injection was prepared daily. The selected dose of iloperidone was active in pharmacological and behavioral paradigms [51-53]. The rats were decapitated $24 \mathrm{~h}$ after the last dose. The livers were quickly removed, frozen in dry ice, and stored at $-80^{\circ} \mathrm{C}$. The blood was collected, and the serum was separated by centrifugation and stored at $-80^{\circ} \mathrm{C}$. Liver microsomes were prepared from individual rats by differential centrifugation in $20 \mathrm{mM}$ Tris/KCL buffer (pH 7.4), including washing with $0.15 \mathrm{mM} \mathrm{KCL}$ to remove the drug administered in vivo, according to the previously used method [54]. 


\subsection{CYP Enzyme Activities in the Liver}

The metabolism of caffeine, warfarin, chlorzoxazone, and testosterone was investigated in vitro using liver microsomes at a linear dependence of product formation on time, protein, and substrate concentration. The activity of CYP1A was determined by measuring the rate of caffeine metabolism (C-8-hydroxylation and 3-N-demethylation) at a substrate concentration of $100 \mu \mathrm{M}$ and incubation time of $50 \mathrm{~min}$. Caffeine and its metabolites were analyzed by HPLC with UV detection [55]. The activity of CYP2C6 was studied by measuring the rate of warfarin 7-hydroxylation at a substrate concentration of $60 \mu \mathrm{M}$ and incubation time of $15 \mathrm{~min}$. Warfarin and its metabolite were analyzed by HPLC with fluorescence detection [56]. The activity of CYP2E1 was estimated by measuring the rate of 6-hydroxylation of chlorzoxazone at a substance concentration of $200 \mu \mathrm{M}$ and incubation time of $20 \mathrm{~min}$. Chlorzoxazone and its metabolites were analyzed by HPLC with UV detection [17]. The activities of CYP2A, CYP2B, CYP2C11, and CYP3A were studied by measuring the rates of cytochrome P450 enzyme-specific reactions: $7 \alpha-, 16 \beta-$, $2 \alpha-, 16 \alpha-, 2 \beta-$-, and $6 \beta$-hydroxylation of testosterone at a substrate concentration of $100 \mu \mathrm{M}$ and incubation time of $15 \mathrm{~min}$. Testosterone and its metabolites were analyzed by HPLC with UV detection $[57,58]$.

\subsection{Determination of CYP Proteins in Liver Microsomes}

The protein levels of the examined CYP enzymes (CYP1A, CYP2B1, CYP2B2, CYP2C11, CYP2E1, CYP3A1, and CYP3A2) in the liver microsomes of control $(n=12)$ and iloperidone treated rats $(n=12)$ were estimated using Western immunoblot analyses. In brief, microsomal proteins $(10 \mu \mathrm{g})$ were separated on $12 \%$ sodium dodecyl sulfate-polyacrylamide gels in a Laemmli buffer system and transferred onto a nitrocellulose membrane. The blots were probed with primary antibodies against appropriate CYP enzymes: monoclonal anti-rat CYP2B and polyclonal anti-rat CYP1A1/2, CYP2C11, CYP2E1, CYP3A1, and CYP3A2. Then, the blots were incubated with the appropriate (anti-mouse IgG or anti-rabbit IgG) horseradish peroxidase-conjugated secondary antibodies, and the bands were visualized by enhanced chemiluminescence. Rats that cDNA-expressed CYP1A2, CYP1B1, CYP2C11 $(5 \mu \mathrm{g})$, CYP2E1 $(2 \mu \mathrm{g})$, CYP3A1, CYP3A2 $(1 \mu \mathrm{g})$ were used as respective standards. The immunoblots were evaluated using a luminescent image analyzer (LAS-1000, (Fuji Film, Tokyo, Japan), and the relative levels of immunoreactivity were quantified using the Image Gauge software (Fuji Film, Tokyo, Japan). The data were normalized to protein based on the $\beta$-actin levels.

\subsection{Analysis of mRNA Level in the Liver}

The total RNA was isolated from frozen liver tissue using a Total RNA Mini kit following the manufacturer's instructions. The RNA was reverse transcribed using a HighCapacity cDNA Reverse Transcription Kit according to the manufacturer's instructions. The expression of the genes encoding the cytochrome P450 enzymes CYP1A1 (Rn01418021_g1), CYP1A2 (Rn00561082_m1), CYP2B1 (Rn01457880_m1), CYP2B2 (Rn02786833_m1), CYP2C11 (Rn01502203_m1), CYP2E1 (Rn00580624_m1), CYP3A1 (Rn03062228_m1), and CYP3A2 (Rn00756461_m1) and the reference gene encoding beta-actin ACTB (Rn00667869_m1) were detected by a real-time polymerase chain reaction (PCR) using TaqMan Gene Expression Master Mix and species-specific TaqMan type probes and primers (TaqMan Gene Expression Assay, Life Technologies). Amplification was performed under the following conditions: $50{ }^{\circ} \mathrm{C}$ for $2 \mathrm{~min}$ and $95^{\circ} \mathrm{C}$ for $10 \mathrm{~min}$ followed by 40 cycles at $95^{\circ} \mathrm{C}$ for $15 \mathrm{~s}$ and $60^{\circ} \mathrm{C}$ for $1 \mathrm{~min}$. Real-time PCR runs were performed using the Bio-Rad CFX96 PCR system (Bio-Rad, Hercules, CA, USA). Gene expression was determined by the 2-delta Ct method using $A C T B$ gene expression as a reference.

\subsection{Analysis of Hormones and Cytokines in the Pituitary and Blood Serum}

The levels of pituitary GHRH and serum concentrations of hormones (GH, corticosterone, $\mathrm{T}_{3}$, and $\left.\mathrm{T}_{4}\right)$ and cytokines (IL-2 and IL-6) of the control $(n=12)$ and chronically 
iloperidone-treated rats $(n=12)$ were measured using ELISA kits following the manufacturer's instructions. The pituitaries were homogenized in phosphate-buffered saline $(\mathrm{pH}=7.0 ; 1: 20 \mathrm{v} / \mathrm{v})$. The homogenates were frozen on dry ice three times and then centrifuged for $5 \mathrm{~min}$ at $5000 \times g$. Absorbance was measured using a Synergy /HTX multi-mode reader (BioTek, Winooski, VT, USA).

\subsection{Statistical Data Analysis}

The statistical significance of changes in enzyme activity, protein level, gene expression, or hormones/cytokine levels was estimated using Student's $t$-test (GraphPad Prism Software Inc., San Diego, CA, USA). The results were regarded as statically significant when $p<0.05$. The obtained results are presented as the mean \pm S.E.M.

\section{Conclusions}

In summary, chronic treatment with iloperidone produces broad changes in cytochrome P450 metabolizing enzymes and cytochrome P450-regulating hormone levels, which points to neuroendocrine regulation of the investigated CYP enzymes, resulting from the central receptor profile of the neuroleptic targeting monoaminergic systems of the brain. It has been documented that dopaminergic $\mathrm{D}_{2}$ [12], adrenergic $\alpha_{2}$ [13], and serotonergic $5-\mathrm{HT}_{1 \mathrm{~A}}$ and $5-\mathrm{HT}_{2 \mathrm{C}}[15]$ receptors of the brain are engaged in the central neuroendocrine regulation of liver cytochrome P450. The action of iloperidone on dopaminergic, serotonergic, and adrenergic receptors may affect the neuroendocrine system and, in turn, the regulation of cytochrome P450 in the liver (discussed in [17]). The observed inhibitory effect of iloperidone on cytochrome P450 enzymes of the CYP1A, CYP2B, CYP2C, and CYP3A subfamilies may lead to pharmacokinetic (metabolic) interactions with concomitantly administered drugs. Moreover, the stimulation of CYP2E1-mediated metabolism of drugs, alcohol, and procarcinogens by iloperidone should also be considered and further investigated.

Author Contributions: P.J.D. and W.A.D. participated in the research design; P.J.D. and W.K. conducted the experiment; P.J.D. and W.A.D. performed the data analysis and wrote the manuscript. All authors have read and agreed to the published version of the manuscript.

Funding: The study was supported by grant Preludium 16 no. 2018/31/N/NZ/01857 from the National Science Centre, Kraków, Poland, and by statutory funds from the Maj Institute of Pharmacology, Polish Academy of Sciences, Kraków, Poland.

Institutional Review Board Statement: All procedures used in this study were conducted in compliance with the rules and principles of the 86/609/EEC Directive and were approved by the Bioethical Committee of the Maj Institute of Pharmacology, Polish Academy of Sciences, Kraków, Poland.

Data Availability Statement: The data are contained within the article.

Acknowledgments: Przemysław Jan Danek acknowledges the support of InterDokMed project no. POWR. 03.02.00-00-I013/16.

Conflicts of Interest: The authors declare no conflict of interest.

\section{References}

1. Zanger, U.M.; Schwab, M. Cytochrome P450 enzymes in drug metabolism: Regulation of gene expression, enzyme activities, and impact of genetic variation. Pharmacol. Ther. 2013, 138, 103-141. [CrossRef]

2. Munro, A.W.; McLean, K.J.; Grant, J.L.; Makris, T.M. Structure and function of the cytochrome P450 peroxygenase enzymes. Biochem. Soc. Trans. 2018, 46, 183-196. [CrossRef]

3. Scott, L.J. Iloperidone. CNS Drugs 2009, 23, 867-880. [CrossRef] [PubMed]

4. Li, P.; Snyder, G.L.; Vanover, K.E. Dopamine Targeting Drugs for the Treatment of Schizophrenia: Past, Present and Future. Curr. Top. Med. Chem. 2016, 16, 3385-3403. [CrossRef]

5. Citrome, L. Iloperidone for schizophrenia: A review of the efficacy and safety profile for this newly commercialised secondgeneration antipsychotic. Int. J. Clin. Pract. 2009, 63, 1237-1248. [CrossRef] [PubMed]

6. Citrome, L. A Review of the Pharmacology, Efficacy and Tolerability of Recently Approved and Upcoming Oral Antipsychotics: An Evidence-Based Medicine Approach. CNS Drugs 2013, 27, 879-911. [CrossRef] [PubMed] 
7. Tarazi, F.; Stahl, S.M. Iloperidone, asenapine and lurasidone: A primer on their current status. Expert Opin. Pharmacother. 2012, 13, 1911-1922. [CrossRef] [PubMed]

8. Cutler, A.J.; Kalali, A.H.; Mattingly, G.W.; Kunovac, J.; Meng, X. Long-term safety and tolerability of iloperidone: Results from a 25-week, open-label extension trial. CNS Spectr. 2013, 18, 43-54. [CrossRef] [PubMed]

9. Tonin, F.; Wiens, A.; Fernandez-Llimos, F.; Pontarolo, R. Iloperidone in the treatment of schizophrenia: An evidence-based review of its place in therapy. Core Evid. 2016, 11, 49-61. [CrossRef]

10. Daniel, W.A. The influence of long-term treatment with psychotropic drugs on cytochrome P450: The involvement of different mechanisms. Expert Opin. Drug Metab. Toxicol. 2005, 1, 203-217. [CrossRef]

11. Deodhar, M.; Al Rihani, S.; Arwood, M.; Darakjian, L.; Dow, P.; Turgeon, J.; Michaud, V. Mechanisms of CYP450 Inhibition: Understanding Drug-Drug Interactions Due to Mechanism-Based Inhibition in Clinical Practice. Pharmaceuticals 2020, 12, 846. [CrossRef]

12. Wójcikowski, J.; Daniel, W.A. The brain dopaminergic system as an important center regulating liver cytochrome P450 in the rat. Expert Opin. Drug Metab. Toxicol. 2009, 5, 631-645. [CrossRef]

13. Sadakierska-Chudy, A.; Haduch, A.; Rysz, M.; Gołembiowska, K.; Daniel, W.A. The role of brain noradrenergic system in the regulation of liver cytochrome P450 expression. Biochem. Pharmacol. 2013, 86, 800-807. [CrossRef]

14. Bromek, E.; Wójcikowski, J.; Daniel, W.A. Involvement of the paraventricular (PVN) and arcuate (ARC) nuclei of the hypothalamus in the central noradrenergic regulation of liver cytochrome P450. Biochem. Pharmacol. 2013, 86, 1614-1620. [CrossRef]

15. Bromek, E.; Daniel, W.A. The regulation of liver cytochrome P450 expression and activity by the brain serotonergic system in different experimental models. Expert Opin. Drug Metab. Toxicol. 2021, 17, 413-424. [CrossRef]

16. Wojcikowski, J.; Daniel, W.A. The Role of the Nervous System in the Regulation of Liver Cytochrome P450. Curr. Drug Metab. 2011, 12, 124-138. [CrossRef] [PubMed]

17. Danek, P.; Bromek, E.; Daniel, W.A. The Influence of Long-Term Treatment with Asenapine on Liver Cytochrome P450 Expression and Activity in the Rat. The Involvement of Different Mechanisms. Pharmaceuticals 2021, 14, 629. [CrossRef]

18. Danek, P.J.; Wójcikowski, J.; Daniel, W.A. The atypical neuroleptics iloperidone and lurasidone inhibit human cytochrome P450 enzymes in vitro. Evaluation of potential metabolic interactions. Pharmacol. Rep. 2020, 72, 1685-1694. [CrossRef]

19. Danek, P.J.; Wójcikowski, J.; Daniel, W.A. Asenapine and iloperidone decrease the expression of major cytochrome P450 enzymes CYP1A2 and CYP3A4 in human hepatocytes. A significance for drug-drug interactions during combined therapy. Toxicol. Appl. Pharmacol. 2020, 406, 115239. [CrossRef] [PubMed]

20. Waxman, D.J.; O'Connor, C. Growth Hormone Regulation of Sex-Dependent Liver Gene Expression. Mol. Endocrinol. 2006, 20, 2613-2629. [CrossRef] [PubMed]

21. Waxman, D.J.; Holloway, M.G. Sex Differences in the Expression of Hepatic Drug Metabolizing Enzymes. Mol. Pharmacol. 2009, 76, 215-228. [CrossRef] [PubMed]

22. Monostory, K.; Kőhalmy, K.; Prough, R.A.; Kóbori, L.; Vereczkey, L. The effect of synthetic glucocorticoid, dexamethasone on CYP1A1 inducibility in adult rat and human hepatocytes. FEBS Lett. 2004, 579, 229-235. [CrossRef] [PubMed]

23. Monostory, K.; Pascussi, J.-M.; Kóbori, L.; Dvorak, Z. Hormonal regulation of CYP1A expression. Drug Metab. Rev. 2009, 41, 547-572. [CrossRef]

24. Audet-Walsh, E.; Auclair-Vincent, S.; Anderson, A. Glucocorticoids and phenobarbital induce murineCYP2Bgenes by independent mechanisms. Expert Opin. Drug Metab. Toxicol. 2009, 5, 1501-1511. [CrossRef] [PubMed]

25. Dvorak, Z.; Pavek, P. Regulation of drug-metabolizing cytochrome P450 enzymes by glucocorticoids. Drug Metab. Rev. 2010, 42, 621-635. [CrossRef] [PubMed]

26. Monostory, K.; Dvorak, Z. Steroid Regulation of Drug-Metabolizing Cytochromes P450. Curr. Drug Metab. 2011, 12, 154-172. [CrossRef]

27. Yamazoe, Y.; Murayama, N.; Shimada, M.; Kato, R. Thyroid hormone suppression of hepatic levels of phenobarbital-inducible P-450b AND P-450e and other neonatal P-450S in hypophysectomized rats. Biochem. Biophys. Res. Commun. 1989, 160, 609-614. [CrossRef]

28. Murayama, N.; Shimada, M.; Yamazoe, Y.; Kato, R. Difference in the Susceptibility of Two Phenobarbital-Inducible Forms, P450IIB1 and P450IIB2, to Thyroid Hormone- and Growth Hormone-Induced Suppression in Rat Liver: Phenobarbi-tal-Inducible P450IIB2 Suppression by Thyroid Hormone Acting Directly, but Not through the Pituitary System. Mol. Pharmacol. 1991, 39, 811-817.

29. Brtko, J.; Dvorak, Z. Role of Retinoids, Rexinoids and Thyroid Hormone in the Expression of Cytochrome P450 Enzymes. Curr. Drug Metab. 2011, 12, 71-88. [CrossRef]

30. Pascussi, J.-M.; Gerbal-Chaloin, S.; Duret, C.; Daujat-Chavanieu, M.; Vilarem, M.-J.; Maurel, P. The Tangle of Nuclear Receptors that Controls Xenobiotic Metabolism and Transport: Crosstalk and Consequences. Annu. Rev. Pharmacol. Toxicol. 2008, 48, 1-32. [CrossRef]

31. Tolson, A.H.; Wang, H. Regulation of drug-metabolizing enzymes by xenobiotic receptors: PXR and CAR. Adv. Drug Deliv. Rev. 2010, 62, 1238-1249. [CrossRef]

32. Daujat-Chavanieu, M.; Gerbal-Chaloin, S. Regulation of CAR and PXR Expression in Health and Disease. Cells 2020, 9, 2395. [CrossRef] [PubMed] 
33. Kretschmer, X.C.; Baldwin, W.S. CAR and PXR: Xenosensors of endocrine disrupters? Chem. Interact. 2005, 155, 111-128. [CrossRef]

34. Chen, J.; Jiang, S.; Wang, J.; Renukuntla, J.; Sirimulla, S.; Chen, J. A comprehensive review of cytochrome P450 2E1 for xenobiotic metabolism. Drug Metab. Rev. 2019, 51, 178-195. [CrossRef] [PubMed]

35. Ingelman-Sundberg, M.; Ronis, M.J.; Lindros, K.O.; Eliasson, E.; Zhukov, A. Ethanol-Inducible Cytochrome P4502E1: Regula-tion, Enzymology and Molecular Biology. Alcohol Alcohol. Suppl. 1994, 2, 131-139.

36. Song, B.-J.; Abdelmegeed, M.A.; Cho, Y.-E.; Akbar, M.; Rhim, J.S.; Song, M.-K.; Hardwick, J.P. Contributing Roles of CYP2E1 and Other Cytochrome P450 Isoforms in Alcohol-Related Tissue Injury and Carcinogenesis. Adv. Exp. Med. Biol. 2019, 1164, 73-87. [CrossRef] [PubMed]

37. Koop, D.R.; Tierney, D.J. Multiple mechanisms in the regulation of ethanol-inducible cytochrome P450IIE1. BioEssays 1990, 12, 429-435. [CrossRef]

38. Gonzalez, F.J.; Ueno, T.; Umeno, M.; Song, B.J.; Veech, R.L.; Gelboin, H.V. Microsomal Ethanol Oxidizing System: Transcrip-tional and Posttranscriptional Regulation of Cytochrome P450, CYP2E1. Alcohol Alcohol. Suppl. 1991, 1, 97-101.

39. Eliasson, E.; Mkrtchian, S.; Ingelman-Sundberg, M. Hormone- and Substrate-Regulated Intracellular Degradation of Cyto-chrome P450 (2E1) Involving MgATP-Activated Rapid Proteolysis in the Endoplasmic Reticulum Membranes. J. Biol. Chem. 1992, 267, 15765-15769. [CrossRef]

40. Martini, R.; Ingelman-Sundberg, M.; Murray, M. Pretranslational and Posttranslational Regulation of Rat Hepatic CYPs 3A2 and 2E1 by Disulfiram. Biochem. Pharmacol. 1997, 54, 1323-1329. [CrossRef]

41. Novak, R.F.; Woodcroft, K.J. The alcohol-inducible form of cytochrome P450 (CYP2E1): Role in toxicology and regulation of expression. Arch. Pharmacal Res. 2000, 23, 267-282. [CrossRef]

42. Chen, G.-F.; Ronis, M.J.J.; Ingelman-Sundberg, M.; Badger, T.M. Hormonal regulation of microsomal cytochrome P4502E1 and P450 reductase in rat liver and kidney. Xenobiotica 1999, 29, 437-451. [CrossRef]

43. Williams, M.T.; Simonet, L.C. Effects of growth hormone on cytochrome P-450j. Biochem. Biophys. Res. Commun. 1988, 155, 392-397. [CrossRef]

44. Tani, Y.; Yamamoto, H.; Kawaji, A.; Mizuno, H.; Fukushige, J.; Hosokawa, T.; Doi, K. Hepatic cytochrome P450 and flavincontaining monooxygenase in male Nts:Mini rat, a transgenic rat carrying antisense RNA transgene for rat growth hormone. Toxicol. Lett. 1999, 106, 159-169. [CrossRef]

45. Takahashi, J.; Furuhata, Y.; Ikeda, A.; Takahashi, M.; Iwata, H.; Kazusaka, A.; Fujita, S. Characterization of hepatic cytochrome P450 isozyme composition in the transgenic rat expressing low level human growth hormone. Xenobiotica 1999, 29, 1203-1212 [CrossRef] [PubMed]

46. Son, M.H.; Kang, K.W.; Kim, E.J.; Ryu, J.H.; Cho, H.; Kim, S.H.; Kim, W.B.; Kim, S.G. Role of glucose utilization in the restoration of hypophysectomy-induced hepatic cytochrome P450 2E1 by growth hormone in rats. Chem. Interact. 2000, 127, 13-28. [CrossRef]

47. Zhang, S.; Cawley, G.F.; Eyer, C.S.; Backes, W.L. Altered Ethylbenzene-Mediated Hepatic CYP2E1 Expression in Growth Hormone-Deficient Dwarf Rats. Toxicol. Appl. Pharmacol. 2002, 179, 74-82. [CrossRef] [PubMed]

48. Doody, E.E.; Groebner, J.L.; Walker, J.R.; Frizol, B.M.; Tuma, D.J.; Fernandez, D.J.; Tuma, P.L. Ethanol metabolism by alcohol dehydrogenase or cytochrome P450 2E1 differentially impairs hepatic protein trafficking and growth hormone signaling. Am. J. Physiol. Liver Physiol. 2017, 313, G558-G569. [CrossRef] [PubMed]

49. Peng, H.M.; Coon, M.J. Regulation of Rabbit Cytochrome P450 2E1 Expression in HepG2 Cells by Insulin and Thyroid Hor-mone. Mol. Pharmacol. 1998, 54, 740-747. [PubMed]

50. Spina, E.; De Leon, J. Clinically relevant interactions between newer antidepressants and second-generation antipsychotics. Expert Opin. Drug Metab. Toxicol. 2014, 10, 721-746. [CrossRef]

51. Strupczewski, J.T.; Bordeau, K.J.; Chiang, Y.; Glamkowski, E.J.; Conway, P.G.; Corbett, R.; Hartman, H.; Szewczak, M.R.; Wilmot, C.A.; Helsley, G.C. 3-[[(Aryloxy)alkyl]piperidinyl]-1,2-Benzisoxazoles as D2/5-HT2 Antagonists with Potential Atypical Antipsychotic Activity: Antipsychotic Profile of Iloperidone (HP 873). J. Med. Chem. 1995, 38, 1119-1131. [CrossRef] [PubMed]

52. Boyda, H.N.; Procyshyn, R.M.; Pang, C.C.Y.; Hawkes, E.; Wong, D.; Jin, C.H.; Honer, W.G.; Barr, A.M. Metabolic Side-Effects of the Novel Second-Generation Antipsychotic Drugs Asenapine and Iloperidone: A Comparison with Olanzapine. PLoS ONE 2013, 8, e53459. [CrossRef]

53. Choi, Y.K.; Tarazi, F.I. Long-Term Effects of Iloperidone on Cerebral Serotonin and Adrenoceptor Subtypes. J. Mol. Neurosci. 2018, 66, 59-67. [CrossRef] [PubMed]

54. Daniel, W.A.; Haduch, A.; Wójcikowski, J. Inhibition and possible induction of rat CYP2D after short- and long-term treatment with antidepressants. J. Pharm. Pharmacol. 2002, 54, 1545-1552. [CrossRef]

55. Kot, M.; Daniel, W.A. Relative contribution of rat cytochrome P450 isoforms to the metabolism of caffeine: The pathway and concentration dependence. Biochem. Pharmacol. 2008, 75, 1538-1549. [CrossRef]

56. Daniel, W.A.; Haduch, A.; Syrek, M.; Boksa, J. Direct and indirect interactions between antidepressant drugs and CYP2C6 in the rat liver during long-term treatment. Eur. Neuropsychopharmacol. 2006, 16, 580-587. [CrossRef] [PubMed]

57. Haduch, A.; Wójcikowski, J.; Daniel, W.A. Effect of neuroleptics on cytochrome P450 2C11 (CYP2C11) in rat liver. Pharmacol. Rep. 2011, 63, 1491-1499. [CrossRef]

58. Wójcikowski, J.; Haduch, A.; Daniel, W.A. Effect of classic and atypical neuroleptics on cytochrome P450 3A (CYP3A) in rat liver. Pharmacol. Rep. 2012, 64, 1411-1418. [CrossRef] 